\title{
Investigation of Thai Manufacturing Public Firms' Characteristics and Financial Strategies towards Financial Performance's Improvement
}

\author{
Janthorn Sinthupundaja and Navee Chiadamrong
}

\begin{abstract}
For a number of years, researchers have described and analyzed inherent factors that may impact on the firms' financial performance. Relationships of firm characteristics and financial strategies towards firms' financial performance improvement are topics that have received much attention in the financial literatures. This study investigates these firms' characteristics relationships, especially the factor of growth, size, and age with the financial strategies in funding their operations, either internal or external financing, and their impact on financial performance improvements. The study collected the data from 242 Thai manufacturing companies listed in the Stock Exchange of Thailand (SET) from six manufacturing industries during 2006-2010. The study was carried out using Structural Equation Modeling (SEM) to identify significant effects among these relationships. The results show that the firm growth has shown negative impact on the firms' liquidity representing the fact that more internal financing has been preferable. The firm size has shown to have negative impact on the level of leverage, but positive impact on the liquidity and financial performance improvement. In addition, the higher level of leverage also raises the higher level of liquidity. And finally, the liquidity significantly deteriorates the growth of financial performance's improvement. However, the factor of age did not find to have any significant impact on our interested variables. These findings have also been supported by existing theories and literatures to confirm the validity.
\end{abstract}

Index Terms-Firm characteristics, age, growth, size, financial strategies, financial performance.

\section{INTRODUCTION}

Over the past few years, there are increasing researches related to the determinants of firm's financing operations and investment strategies towards the firm performance. Performance is the function of the ability of an organization to gain and manage the resources in several different ways to develop competitive advantages [1]. It is divided into financial performance and non-financial performance. In this study, we focused on the firms' financial performance. References [2]-[5] have used financial performance as an indicator for firms' success. In the past research, the

Manuscript received October 25, 2013; revised December 28, 2013. This work was supported by the research grant from Bangchak Petroleam Public Company Limited. The authors are grateful for this financial support.

J. Sinthupundaja is with the Logistics and Supply Chain Systems Engineering (LSCSE), Sirindhorn International Institute of Technology (SIIT) Thammasat University, Pathum Thani, Thailand, 12121 (e-mail: miniiz_june@hotmail.com ).

N. Chiadamrong is with the Industrial Engineering Program, Sirindhorn International Institute of Technology (SIIT), Thammasat University, Pathum Thani, Thailand, 12121 (e-mail: navee@ siit.tu.ac.th). determinants of the firms' characteristics may include growth opportunities, size, age, liquidity, asset structure, and profitability [6], [7]. In this study, five interested factors (growth, size, age, liquidity, and level of leverage or capital structure) have been identified to test their effects towards the firm financial performance's improvement. With their effects, one can pay more attention on them more closely as they play a major role in deciding the investment direction and prosperity of the firms. As a result, the objective of this study is to empirically investigate the relationships between firms' characteristics factors through their financial strategies based on the case study of the manufacturing firms listed in Thailand's stock market. Structural Equation Modeling (SEM) is applied using AMOS to analyze the significant effect among these relationships.

\section{BACKGROUND OF THE STUDY}

Firms usually develop their financial energies and operating performance through acquisition and merger or outsourcing [8] as well as extend their expanding plants and equipment, updating technologies, and innovating products to maintain competitive advantages and sustainable [9]. Consequently, firms generally keep their competitiveness to rely on successful capital expenditures strategies and funding sources during an effective promotion of strategies and planning. Reference [10] discussed financing hierarchy from the view of asymmetric information, known as the Pecking Order Theory, and proposed the priority of financing strategies. Corporations prefer internal financing, especially for reserved surplus, as interest costs are not involved, and the limitations are less than other modes. However, if the source of funds for internal financing is less than capital expenditures, the corporations will then consider external funds for financing. Reference [11] investigated the capital structures chosen by 313 CFOs, and how European professionals put theory into practice. The result indicated that the Pecking Order Behavior exists and its behavior is not affected by asymmetrical information. Reference [12] studied the financing strategy of European public firms, and found 60 percent of firms advocated the Financing Hierarchy system, which meets the Pecking Order Theory.

Reference [13] found that a higher Market-to-Book value (M/B) has a lower target Debt Ratio (DR). Firms with high $\mathrm{M} / \mathrm{B}$ usually obtain higher investment evaluation in equity securities from investors. When firms issue equity securities for financing, they will increase price per shares to reveal good performance for attracting investors. As a result, firms' operational factors possibly have relations associated with 
financing strategies.

Growth, size, and age are considered to be important characteristic factors, which are often used to be the determinants of firm performance [2], [3], [5], and [14]. Growth is one of the important determinants to decide the financing strategy and structure of the firms, representing the growth opportunities and the firm expansion. Size of the firms also brings different levels of credit evaluation. A major obstacle to expansion for firms at the bottom of the size and productivity distribution is the limited availability of credit [15]. Large firms are much more likely to report having more access to formal credits [16] and internalize many of the capital allocation functions carried out by financial markets and financial intermediaries [17]. In opposite, small firms are likely to face tougher obstacles in obtaining finance, accessing legal systems, or dealing with corruption [17]. Reference [18] found that the larger firms prefer to follow the Pecking Order Theory, while medium and small firms would not follow the theory if the financing environment is favorable when inspecting whether the financial structure of firms listed in 2004 conforms to the Pecking Order Theory. Age may imply basic aspects of firms. The impact of age on the firm performance is still very much in doubt in which conflicting results have often been reported. For example, old age firm indicates lower operational risks [19] and it could improve firm financial performance. In addition, the probability that a firm will fail could decrease with the firm age [20]. On the other hand, reference [21] suggested that as firms grow older, their profitability tends to decline.

Referring the financing strategies, internal funds of the firms depend on their level of liquidity. Liquidity refers to how quickly and cheaply a firm's assets can be converted into cash [22]. Firms hold a certain amount of liquid balance for various motives such as precautionary, speculative and transactional [23]. Reference [10] and [11] studied relationships between liquidity and firm performance. On the other hand, the level of leverage representing by the capital structure shows the degree to which a business is utilizing borrowed money. It is different from one firm to others depending on firm management and financial strategy. It is also the balancing of risk and return. Investors would analyze relative financial and operating circumstance of the firm to make their investment decisions. Reference [24] found that corporate managers give preference to internal funds for financing, second is external funds, when carrying out a practical research on financing modes chosen by American corporations. If the source of funds for internal financing is less than capital expenditures, the corporation will then consider external funds for financing.

With external funding, the level of leverage is considered by many researchers as an important indicator for funding decisions [12], [13], [15], and [16]. When firms increase debts, the corporate value will depreciate due to higher bankruptcy risk and agency costs after the debts have increased to a certain level. The offset of debt and equity is referred to as the Trade-off Theory. Reference [25] investigated the funding decision-making of European public firms and found that 50 percent of the firms pursue maintaining a target debt standard, which conforms to the Trade-off Theory. Reference [12] studied the capital structure of the Portuguese service industry from 1999 to 2003 and found that debt could promote the improvement of managerial results and solve agency problems between shareholders and creditors. Thus, large service firms tend to have higher amount of debt, which conforms to the Trade-off Theory.

\section{THEORETICAL FRAMEWORK AND HYPOTHESES}

In our theoretical framework, there are three tiers of the main factors to be tested. As seen in Fig. 1, the first tier is related to firm characteristic factors, which consist of the growth (F1), size (F2), and age (F3) of the firms. The second tier indicates the financial strategies for external and internal funding, which are measured through the level of leverage (F4) and the liquidity (F5). Finally, the last tier evaluates the firm financial performance's improvement (F6).

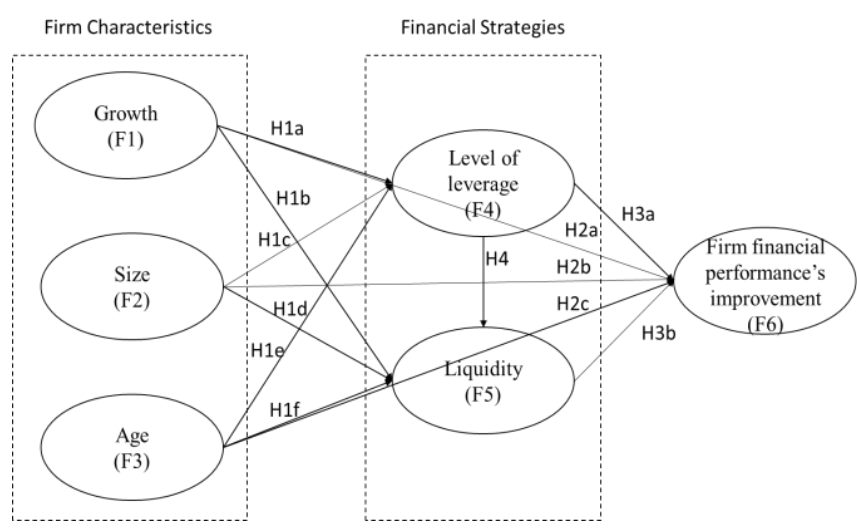

Fig. 1. Overview of hypotheses

\section{A. Relationships between Firm Characteristic Factors and Financial Strategies for Funding}

Hypotheses 1a-1f propose that the firms' characteristics including the factors of growth, size, and age have significant effect on the level of firm leverage and liquidity. This is to evaluate the impact of firms' characteristics towards their financial strategies. Normally, the management chooses finanical strategies based on private information about future firm growth as it is the most important determinant of capital structure choice [26]. Growth is capital assets that add value to the firm but cannot be collateralized and do not generate current taxable income [27]. On the other hand, growing business needs more capital and resources to expand and maintain its competitiveness. According to the Pecking Order Theory, if the firms use internal financing by funds from their operations, their level of liquidity would be deteriorating. If the internal funds are not sufficient, firms would then use external financing and it would bring up the level of debt as well as their leverage.

Many researchers have suggested that the size of the firm, level of leverage and liquidity are somewhat related. Reference [28] stated that larger firms seem to have a lower bankruptcy chance and they possess higher debt than smaller firms. Moreover, reference [29] also suggested that larger firms obtain higher investment evaluation from financial institutes for their credits and this indicates the positive relationship between the firms' size and their level of 
leverage. With regard to the level of liquidity, reference [30] predicted an inverse relationship between the firm size and the cash holdings because larger firms tend to invest in different growth opportunities instead of stockpiling it predicted. As the firm is growing, the opportunities to invest in different operations also increase [31]. Then, it is interesting to test the effect of age to the financial strategies of firms (both liquidity and level of leverage). Hence:

- H1a: Growth has significant effect on the level of leverage of the firm.

- H1b: Growth has significant effect on the liquidity of the firm.

- H1c: Size has significant effect on the level of leverage of the firm.

- H1d: Size has significant effect on the liquidity of the firm.

- H1e: Age has significant effect on the level of leverage of the firm.

- H1f: Age has significant effect on the liquidity of the firm.

\section{B. Relationship between Firm Characteristic Factors and} Financial Performance Improvement

Hypotheses 2a-2c propose that the growth, size, and age of the firms have significant direct impact on firm financial performance's improvement. Growth or growth opportunity is often used to be a determinant of firm performance. Growth generates more profits and eventually improves business performance [32]. The size of the firm also affects the financial performance in many ways. Larger firms gain advantages of economies of scale. They can exploit their scales by having more power for bargaining, and being more efficient compared to small firms [2]. However, when firms become too large, they may face inefficiency of management and slow decision making, which could eventually reduce their performance. Many authors have also considered age as an important factor influencing firm financial performance. For instance, the firm age can positively affect the financial performance since older firms have more experience and enjoy superior performance [2]. However, some argued that firm age can influence firm financial performance negatively. Reference [21] showed that the firms' financial performance decline with the age of the firm since firms are old and become inefficient. Hence:

- H2a: Growth has significant effect on firm financial performance's improvement.

- H2b: Size has significant effect on firm financial performance's improvement.

- H2c: Age has significant effect on firm financial performance's improvement.

\section{Relationship between Firm Financial Strategies and Firm Financial Performance}

Hypotheses $3 \mathrm{a}$ and $3 \mathrm{~b}$ propose that the level of leverage and liquidity of the firm significantly affects firm financial performance's improvement. The level of leverage or capital structure shows how business finances its operations and costs. It is relating to how a firm manages its capital structure. Capital structure is the balancing between risk and return [14]. The higher ratio of leverage shows that firms externally borrow money from banks and other financial institutions in high proportion. On the other hand, the liquidity shows the amount of cash or cash equivalent that firms hold or have an ability to convert assets to cash. For operations of the firms to run smoothly, optimum level of liquidity and its surplus within the firm should be maintained.

There are two opposing effects on the capital structure, depending on the selection of financial strategies for funding the firms' investment. Debt can somehow improve firm performance because managers in debt are in stress, in pressure and need to make value-maximizing decision. On the other hand, [33] and [7] suggested that the correlation between capital structure and firm performance is negative. As, a high level of debt brings high financial cost, if borrowed debt cannot generate sufficient income or the firm cannot utilize that loan well enough, the financial performance of that firm would eventually be deteriorating. Good and proper liquidity management helps firms to maintain the surplus, reduce risk, and improve company survival rate [34]. Reference [6] stated that the liquidity would allow a firm to deal with unexpected contingencies and to cope with its obligations during periods of low earnings. From this perspective, we can suggest the following hypotheses:

- H3a: Level of leverage has significant effect on firm financial performance's improvement

- H3b: Liquidity has significant effect on firm financial performance's improvement

\section{Relationship between Liquidity and Level of Leverage}

Hypothesis 4 proposes that the liquidity of the firm significant affects the level of leverage. Many literatures studied the relationship between the liquidity and leverage of firms [23], [35], and [36]. These findings have suggested that the level of leverage can significantly affect the liquidity of firms either positively or negatively. Hence:

- H4: Level of leverage has significant effect on the liquidity of the firm.

\section{ReSEARCh DESIGN}

Firms under the study are listed in Stock Exchange of Thailand (SET). SET is the Thailand national stock exchange. Operations of Stock Exchange of Thailand (SET) started on April 30, 1975 under the Securities Exchange of Thailand ACT, B.E. 2517 (1974). In total, there are eight industries listed in SET, including Agro \& Food Industry, Consumer Product, Consumer Product, Industrials, Property \& Construction, Resources, Technology, Finance, and Services. However, in this study, only six manufacturing industries are included as financial and service industries are excluded due to their non-manufacturing nature. We used financial data from Thai public manufacturing firms listed in SET from 2006 to 2010, drawn from their income statements and balance sheets. The entire dataset contains 354 firms, however, many firms are excluded because essential data are missing due to merging, suspension, and bankruptcy. Therefore, a dataset of 242 firms remains so the total numbers of observations in five years are 1,210 observations. 
Table I shows the list of industries and the number of firms used in the analysis. Each earlier mentioned latent factor has been indicated by one or more variables for representing possible dimensions of that factor.

\begin{tabular}{|c|c|}
\hline Industry & Number of firms \\
\hline Agro \& Food Industry & 37 firms \\
\hline Consumer Product Industry & 33 firms \\
\hline Industrials Industry & 67 firms \\
\hline Property \& Construction Industry & 50 firms \\
\hline Resources Industry & 23 firms \\
\hline Technology Industry & 32 firms \\
\hline Total & 242 firms \\
\hline
\end{tabular}

Table II summarized variables in each latent factor. There are 19 variables representing 6 latent factors. Then, highly correlated variables and variable loaded on multiple constructs will be deleted during the purification of the measurement model's analysis. For a brief explanation of these factors, firm characteristics consist of growth, size, and age of the firms. Growth depicts the firm future opportunity to survive and expand. In this study, we used growth ratio of total assets, growth ratio of sales, growth ratio of expenses, and growth ratio of shareholders' equity as indicators of firm growth. Firm size is represented by the natural logarithm of sales (LnSales), natural logarithm of market value (LnMarket value), and natural logarithm of total assets (LnTotal assets). The logarithmic transformation is needed to convert these variables that grow at a constant percentage rate to be a linear function of time. For example, reference [27] and [28] used natural logarithm of sales, market value, and total assets as indicators of the firm size. Age is represented by number of days listed in the Stock Exchange of Thailand (SET) and number of days established.

TABLE II: VARIABLES IN EACH LATENT FACTOR UNDER OUR STUDY

\begin{tabular}{|c|c|c|c|c|}
\hline \multicolumn{2}{|r|}{ Firm Characteristics } & \multicolumn{2}{|c|}{$\begin{array}{l}\text { Firm Financial Strategies } \\
\end{array}$} & $\begin{array}{l}\text { Firm Financial Performance's } \\
\text { Improvement }\end{array}$ \\
\hline $\begin{array}{l}\text { Growth } \\
(\mathrm{F} 1)\end{array}$ & $\begin{array}{l}\text { - Growth ratio of total assets (V1) } \\
\text { - Growth ratio of sales (V2) } \\
\text { - Growth ratio of expenses (V3) } \\
\text { - Growth ratio of equity (V4) }\end{array}$ & $\begin{array}{l}\text { Level of leverage } \\
\text { (F4) }\end{array}$ & $\begin{array}{l}\text { - Debt to equity ratio (V10) } \\
\text { - Debt to total assets ratio (V11) } \\
\text { - Current liabilities over total assets (V12) } \\
\text { - Long-term liabilities over total assets (V13) }\end{array}$ & $\begin{array}{ll}\text { Financial } & \text { - ROE growth (V18) } \\
\text { Performance } & \text { - ROA growth (V19) } \\
\text { (F6) } & \end{array}$ \\
\hline $\begin{array}{l}\text { Size } \\
(\mathrm{F} 2)\end{array}$ & $\begin{array}{l}\text { - Ln(Sales) (V5) } \\
\text { - Ln(Market Value) (V6) } \\
\text { - Ln(Total assets) (V7) }\end{array}$ & $\begin{array}{l}\text { Liquidity } \\
\text { (F5) }\end{array}$ & $\begin{array}{l}\text { - Cash (V14) } \\
\text { - Inventory turnover (V15) } \\
\text { - Current ratio (V16) } \\
\text { - Quick ratio (V17) }\end{array}$ & \\
\hline $\begin{array}{l}\text { Age } \\
\text { (F3) }\end{array}$ & $\begin{array}{l}\text { - No. of days listed in SET (V8) } \\
\text { - No. of days established (V9) }\end{array}$ & & & \\
\hline
\end{tabular}

Firms' financial strategies are represented by the level of leverage and corporate liquidity of the firm. Debt management is crucial because the firm must decide how and when to pay off liabilities according to available cash and interest rates. Level of leverage in this study is represented by debt to equity ratio, debt to total assets ratio, current liabilities over total assets, and long-term liabilities over total assets while the liquidity of the firm is measured through cash, inventory turnover, current ratio, and quick ratio. Inventory turnover is calculated by sales over average inventory level. Current ratio is calculated by the current asset over current liabilities. Quick ratio is calculated by the difference between current assets and inventories over current liabilities.

\begin{tabular}{lrr}
\multicolumn{3}{c}{ TABLE III: LISTED OF VARIABLES } \\
\hline \multicolumn{1}{c}{ Variables } & Minimum & Maximum \\
\hline Growth ratio of sales (V1) & -2.1308 & 21.9414 \\
Growth ratio of total assets (V2) & -3.9306 & 13.9632 \\
Growth ratio of expenses (V3) & -0.3700 & 18.6000 \\
Growth ratio of shareholder's equity (V4) & -2.4716 & 34.1858 \\
Ln(Sales) (V5) & -3.9377 & 4.2555 \\
Ln(Market Value) (V6) & -2.3767 & 3.7863 \\
Ln(Total asset) (V7) & -2.2630 & 4.0355 \\
No. of days listed in SET (V8) & -2.3837 & 2.7245 \\
No. of days firms established (V9) & -1.7510 & 3.0355 \\
Debt over total assets (V10) & -0.1394 & 25.1296 \\
Debt over equity (V11) & -0.9198 & 18.3850 \\
Current liabilities over total assets (V12) & -1.6816 & 4.0590 \\
Long-term liabilities over total assets (V13) & -1.1692 & 7.7537 \\
Cash (V14) & -0.1944 & 19.2157 \\
Inventory turnover (V15) & -0.3148 & 25.1248 \\
Current ratio (V16) & -0.3467 & 23.3065 \\
Quick ratio (V17) & -0.2244 & 24.1588 \\
ROA growth (V18) & -17.3860 & 13.2818 \\
ROE growth (V19) & -29.8699 & 11.5382 \\
\hline
\end{tabular}

Firm performance's improvement is the improvement of an outcome of financial performance. It represents the potential of business to manage and use resources in different ways to reach its goal efficiently. Firm performance can be measured through financial performance and non-financial performance. We focus on financial aspect of performance. In this study, firm financial performance's improvement is represented by proliferation of Return on Equity (ROE) and proliferation of Return on Asset (ROA). Return on Equity (ROE) is calculated by net income over shareholders' equity. Return on Asset (ROA) is calculated by net income over total assets.

All raw data have been standardized (also called $\mathrm{Z}$ scores) in order to eliminate the bias of scales regarding the effects of coefficient factors. Table III lists all variables and their ranges used in the study. The data include maximum and minimum values in each variable.

\section{RESULTS}

This study used Structural Equation Modeling (SEM) through AMOS 18.0 distributed by SPSS to analyze the research hypotheses. SEM is a statistical technique for testing, presenting, and eliminating relationships between variables. It is a tool for analysis of the patterns of correlation/covariance among variables as well as individual variances. It attempts to analyze complicated causal models by incorporating unobserved (latent) variables and observed (measured) variables. Usually, the maximum likelihood (ML) estimation method is employed, but the data in this research are not normally distributed. As a result, Asymptotically Distribution-Free (ADF) estimator is used instead. ADF estimator does not require normality assumption [37]. Results from a two-step procedure of SEM consisting of the measurement model and the structural model will be presented as followed: 


\section{A. Measurement Model}

In this step, Confirmatory Factor Analysis (CFA) was used to validate the measures of constructs for developing the measurement. CFA is a more effective method for assessing unidimensionality than the methods of exploratory factor analysis, coefficient alpha, and item-to-total correlation. The purpose is to ensure unidimensionality of the multiple-item constructs or low item-to-constructs and to eliminate unreliable items [38]. Highly correlated variables are eliminated into a single variable, and variables loaded on multiple constructs were deleted from the model prior to testing. CFA results in elimination of individual items including the growth ratio of equity (V4), natural logarithm of total assets (V7), No. of days established (V9), current liabilities over total assets (V12), long-term liabilities over total assets (V13), current ratio (V16), and quick ratio (V17) because of high correlation and high residuals.

After elimination of the above mentioned variables, the following results can be presented. The Chi-square to degree of freedom ratio of the model is 2.588 which is less than 3.00 [39]. The Root Mean Square Error of Approximation (RMSEA) is equal to 0.036 , which is within the acceptable level for this measure of fit (RMSEA < 0.05) [40]. Goodness of Fit Index (GFI) is 0.961 , which also presents a good fit (GFI > 0.90) [40]. The Tucker Lewis Index (TLI), Comparative Fit Index (CFI), and Normed Fit Index (NFI) are $0.940,0.939$, and 0.906 , respectively. The acceptable level of these 3 measures of fit should be higher than 0.90 [40]. These results show all required goodness of fit index values are complied with the suggested values and confirm that our model is valid and reliable. The acceptable values and obtained values can be summarized in Table IV.

TABLE IV: ACCEPTABLE VALUES AND OBTAINED VALUES OF GOODNESS

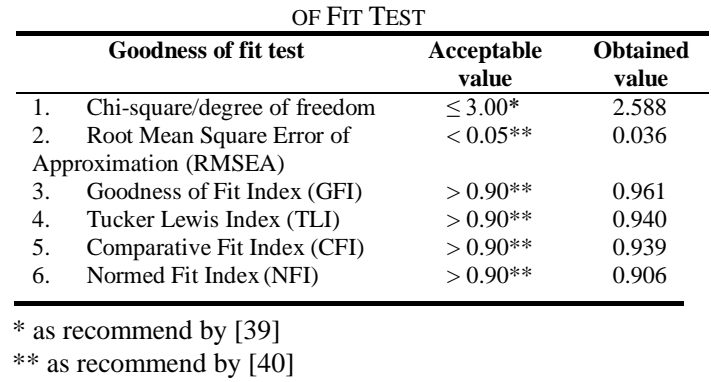

\section{B. Structural Model}

The result shows that, under $95 \%$ confidence level, the growth factor negatively affects the liquidity with the $p$-values of $0.034(p<0.05)$. Firm size has a negative impact on the level of leverage with the $p$-value of $0.000(p<0.05)$. Size factor positively affects the liquidity with the $p$-value of $0.000(p<0.05)$. Moreover, the size factor also has a direct impact on firm financial performance's improvement with the $p$-value of $0.004(p<0.05)$. Liquidity negatively affects the firm financial performance's improvement with the $p$-value of $0.025(p<0.05)$. Finally, the level of leverage positively affects the liquidity with the $p$-value of $0.000(p<$ $0.05)$.

However, there is no significant direct effect of firm growth to the level of leverage and firm financial performance's improvement. In addition, the level of leverage has no impact on the firm financial performance's improvement. Age of firms does not show to affect any financial strategies and firm financial performance's improvement. The results of the path analysis can be summarized in Fig. 2 and Table V. The discussion will be addressed in the following section.

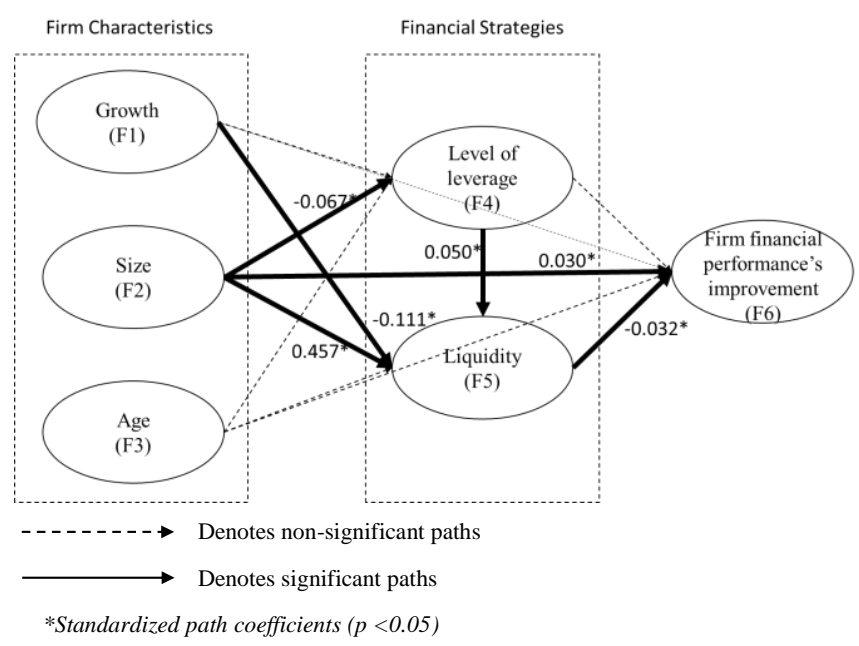

Fig. 2. Significant paths in structural model.

\begin{tabular}{llrl}
\multicolumn{5}{c}{ TABLE V: STRUCTURE MODEL } & & \\
\hline \multicolumn{1}{c}{ From } & \multicolumn{1}{c}{ To } & Estimate & $\boldsymbol{P}$ \\
& & & \\
\hline Growth (F1) & Level of leverage (F4) & .018 & 0.534 \\
Size (F2) & Level of leverage (F4) & -.067 & $0.000^{*}$ \\
Age (F3) & Level of leverage (F4) & .003 & 0.737 \\
Size (F2) & Liquidity (F5) & .457 & $0.000^{*}$ \\
Growth (F1) & Liquidity (F5) & -.111 & $0.034^{*}$ \\
Age (F3) & Liquidity (F5) & -.024 & 0.325 \\
Level of leverage (F4) & Liquidity (F5) & .050 & $0.000^{*}$ \\
Level of leverage (F4) & Performance (F6) & -.007 & 0.096 \\
Liquidity (F5) & Performance (F6) & -.032 & $0.025^{*}$ \\
Growth (F1) & Performance (F6) & -.007 & 0.808 \\
Size (F2) & Performance (F6) & .030 & $0.004^{*}$ \\
Age (F3) & Performance (F6) & -.007 & 0.282 \\
*Significant at $p<0.05$ & & &
\end{tabular}

\section{DISCUSSION AND MANAGERIAL IMPLICATIONS}

Six paths are significant $(p<0.05)$. These paths consist of $\mathrm{H} 1 \mathrm{~b}$, testing the effect of growth on liquidity; H1c and H1d, testing the effect of size on level of leverage and liquidity, respectively; $\mathrm{H} 2 \mathrm{~b}$, representing the path from size to firm financial performance's improvement; $\mathrm{H} 3 \mathrm{~b}$, testing the effect of liquidity on financial performance's improvement; and H4, testing the effect of level of leverage on liquidity [19].

\section{A. The Effect of Growth on Liquidity is Significant and Negative $(H 1 b)(p<0.05)$}

As firms are growing, their investment opportunity will increase. Thus, the firm is prone to spend cash in order to expand their business by various investment choices which results in a negative effect of growth on liquidity [19]. According to the Pecking Order Theory, the firms use internal financing by funds from their operations, their level of liquidity would be deteriorating as a result.

\section{B. The Effect of Size on Level of Leverage is Significant and Negative $(\mathrm{Hlc})(p<0.05)$}

This finding elaborates the fact that the level of leverage is negatively affected by the firms' size. Large firms in this 
study show to have a lower level of leverage as compared to small firms, this may be due to the fact that larger firms prefer to follow the Pecking Order Theory where internal financing is more favorable as interest costs are not involved as reported by reference [19]. Reference [27] also suggested that small firms find it more difficult to issue equity than larger firms. As a result, they tend to use external financing and hence increase the level of leverage.

\section{The Effect of Size on Liquidity is Significant and Positive (HId) $(p<0.05)$}

This finding is somehow opposite to the one with the factor of growth. As the firms get bigger in size, their levels of liquidity have shown to be better. Since in this study, the size of firms was measured by the amount of sales and their market value, it is not surprising to see that the factor of size has a positive significant impact on the liquidity. Reference [22] also reported the same positive relationship between the firm size and its liquidity.

\section{The Effect of Size on Firm Financial Performance's Improvement is Significant and Positive $(\mathrm{H} 2 b)(p<0.05)$}

Size is only firm characteristics factors in our study, which shows to directly affect the firm financial performance's improvement. Large firms tend to be more efficient as they can exploit the advantages of economies of scale, skilled workers, and market power. As a result, it positively helps improve the firms' financial performance while the factors of growth and age did not show any direct influence on the financial performance. Reference [41] also supported this finding by suggesting that the large firms tend to have more abilities to diversify their risk than the small firms. Thus, the factor of size has shown to significantly impact on the firms' financial performance as presented by our result.

\section{E. The Effect of Liquidity on Firm Financial Performance's Improvement is Significant and Negative (H3b) $(p<0.05)$}

This result is consistent with the finding in reference [42], which reported that the high liquidity means too many assets are not being properly utilized. If available current assets are not utilized well enough, the firms would face the problem of low rates of return and lead to a negative impact of liquidity on the financial performance.

\section{$F$. The Effect of Level of Leverage on Liquidity is Significant and Positive (H4) $(p<0.05)$.}

Reference [43] stated that when firms possess high leverage, they tend to have high liquidity because of high degree of the uncertainty of refinancing for loans. High degree of leverage brings firms high risk and high uncertainty. Thus, firms tend to increase corporate liquidity to cope with those uncertainty.

\section{G. Non-Significant Paths}

There are 6 paths which are not significant. These paths include H1a, testing the effect of growth on the level of leverage; H1e and H1f, testing the effect of age on the level of leverage and the liquidity, respectively; $\mathrm{H} 2 \mathrm{a}$ and $\mathrm{H} 2 \mathrm{c}$, testing the effect of growth and age on the firm financial performance's improvement; and H3b, representing the path from level of leverage to the firm financial performance's improvement.

As the firm growth does not show to significantly impact on the level of leverage (H1a) but shows to negatively affect the liquidity (H1b), this result may imply that as the growth is one of important determinants to decide the financial strategy, the level of leverage referring firms using more of the external financing in this study does not show to depend much on the growth factor. So, the financial institutes seem to evaluate the financing firms based on the current firms' status such as size and liquidity rather than future or perspective growth.

Age is also not found to be significantly affect any of our interested factors as $\mathrm{H} 1 \mathrm{e}, \mathrm{H} 1 \mathrm{f}$, and $\mathrm{H} 2 \mathrm{c}$ were rejected. As a result, it may be able to conclude that the firms' financial strategy and their financial performance's improvement do not depend on their age. The duration of firms listed in SET does show to have any impact neither on the level of leverage nor the liquidity of the firms. As a result, no matter how long the firm has stayed in the stock market does not seem to influence their operations and performance.

Firm growth does not show to have a direct impact on their financial performance's improvement $(\mathrm{H} 2 \mathrm{a})$. This finding suggests that the growth of the firms alone would not cause any impact on the financial performance's improvement. Rather, it must be able to improve the firm's strategic actions and drive the firm operations for the success before the financial outcomes can be improved.

Lastly, it is also surprising to see that the firm level of leverage of the firm does not show to affect the firm performance's improvement (H3a). Our data set of selected public manufacturing firms in SET as a case study show no significant link between the level of leverage and the financial performance's improvement. Different levels of leverage or capital structure do not guarantee better or worse financial performance of these firms. The success or failure of the firms in this study show much to depend on other factors (e.g., size and liquidity) beyond merely debt policy as well as the firm characteristics factors of age and pure growth as previously mentioned.

\section{LIMITATION AND FURTHER STUDIES}

The limitation of this study is an inability to control external factors such as national economics, interest rate, and inflation rate. These external factors could also affect our interested factors, firm characteristics, financial strategies and firm financial performance. Further studies may consider this issue to make the results more completed. Moreover, the difference of industries should be considered so that the results can be separately analyzed and compared between industries because determinants of different industries may be different and significant. Extension study may include the study of external factors, differences of industries, and time series effect. The findings presented in this paper should be considered with these limitations.

\section{REFERENCES}

[1] S. Iswatia and M. Anshoria, "The influence of intellectual capital to financial performance at insurance companies in Jakata Stock 
Exchange (JSE)," in Proc. the 13th Asia Pacific Management Conference, Melbourne, 2007.

[2] J. U. Duncombe, "Infrared navigation-Part I: An assessment of feasibility," IEEE Trans. Electron Devices, vol. ED-11, pp. 34-39, Jan. 1959.

[3] A. Y. Almajali, S. A. Alamro, and Y.Z. A. Soub, "Factors affecting the financial performance of jornian insurance companies listed at amman stock exchange," Journal of Management Research, vol. 4, no. 2, 2012

[4] A. M. Alzharani, A. B. C. Ahmad, and K. S. Aljaaidi, "An empirical investigation of factors associated with firm performance evidence from Kingdom of Saudi Arabia," in Proc. the 2011 International Conference on E-business, Management and Economics, Singapore, 2011.

[5] P. Agustinus and P. Rachmadi, "Determinants of corporate peformance of listed companies in Indonesia," MPRA Paper, 2008.

[6] K. M. Khalifa and Z. Shafii, "Factors affecting the financial performance of non-oil industrial companies listed on Libyan Stock Market (LSM)," in Proc. the 4th International Conference on Business and Economic Reseach, Bandung, 2013.

[7] P. Liargovas and K. Skandalis, "Factor affecting firms financial performance: The case of Greece," Global Business and Management Research: An International Journal, vol. 2, no. 2-3, 2010.

[8] N. P. A. Doan and J. D. Nguyen, "Firm characteristics, capital structure and operational performance: A Vietnamese study," in Proc. the APEA 2011 Conference, Busan, 2011.

[9] M. R. Díaz and T. F. E. Rodríguez, "A model of strategic evaluation of a tourism destination based on internal and relational capabilities," Journal of Travel Research, vol. 46, no. 4, pp. 368-380, 2008.

[10] P. Kongkiti and K. Rapee, "Supplier management: Perspectives from large manufacturers in Thailand," International Journal of Management and Enterprise Development, vol. 5, pp. 205-224, 2008.

[11] S. Myers and N. Majluf, "Corporate financing and investment decisions when firms have information that investors do not have," Journal of Financial Economics, vol. 13, pp. 187-221, 1984.

[12] D. Brounen, A. D. Jong, and K. Koedijk, "Capital structure policies in Europe: Survey evidence," Journal of Banking and Finance, vol. 30, no. 5, pp. 1409-1442, 2006.

[13] V. Beattie, A. Goodacre, and S. J. Thomson, "International lease-accounting reform and economic," The International Journal of Accounting, vol. 41, no. 1, pp. 75-103, 2006.

[14] A. Hovakimian, T. Opler, and S. Titman, "The debt-equity choice," Journal of Financial and Quantitative Analysis, vol. 36, p. 1-24, 2001.

[15] T. A. Muritala, "An empirical analysis of capital structure on firm's performance in Nigeria," International Journal of Advances in Management and Economics, pp. 116-124, 2012.

[16] A. Kochar, "An empirical investigation of rationing constraints in rural credit markets in India," Journal of Development Economics, vol. 53 , pp. 339-371, 1997.

[17] J. V. Biesebroeck, "Firm size matters: Growth and productivity growth in Afican manufacturing," Economic Development and Cultural Change, vol. 53, no. 3, pp. 545-583, 2005.

[18] T. Beck, A. D. Kunt, and V. Maksimovic, "Financial and legal constraints to growh: Does firm size matter?" The Journal of Finance, vol. 60, no. 1, 2005.

[19] J. Ni and M. Yu, "Testing the pecking-order theory," The Chinese Economy, vol. 41, no. 1, pp. 97-113, 2008.

[20] K. H. Shih and K. C. Fan, "Analyzing financing strategy of public manufacturing companies," Industrial Management and Data Systems, vol. 109, no. 6, pp. 775-792, 2009.

[21] D. S. Evans, "The relationship between firm growth, size, and age: Estimates for 100 manufacturing industries," The Journal of Industrial Economics, vol. XXXV, no. 4, June 1987.

[22] C. Loderer and U. Waelchli, "Firm age and performance," MPRA Paper, 2010.

[23] A. Gill and N. Mathur, "Factors that influence corporate liquidity holdings in Canada," Journal of Applied Finance \& Banking, vol. 1, no. 2, pp. 133-153, 2011

[24] Z. Isshaq and G. A. Bokpin, "Corporate liquidity management of listed firms in Ghana," Asia Pacific Journal of Business Administration, vol. 1, no. 2, pp. 189-198, 2009

[25] G. Donaldson, Corporate Debt Capacity: A Study of Corporate Debt Policy and the Determination of Corporate Debt Capacity, Boston: Division of Research, Harvard Graduate School of Business Administration, 1961.

[26] Z. Serrasqueiro, "Firms' growth opportunities and profitability: A nonlinear relationship," Applied Financial Economics Letters, vol. 3 , no. 6 , pp. $373-379,2007$.
[27] C. Chang, A. C. Lee and C. F. Lee, "Determinants of capital structure choice: A structural equation modeling approach," The Quarterly Review of Economics and Finance, vol. 49, pp. 197-213, 2009.

[28] S. Titman and R. Wessels, "The determinants of capital structure choice," The Journal of Finance, vol. 43, no. 1, 1988.

[29] C. C. Yang, C. F. Lee, Y. X. Gu, and Y. W. Lee, "Co-determination of capital structure and stock returns-A LISREL approach an empirical test of Taiwan stock markets," The Quarterly Review of Economics and Finance, vol. 50, pp. 222-233, 2010.

[30] A. A. Bevan and J. Danbolt, "Capital structure and its determinants in the UK - A decompositional analysis," Applied Financial Economics, vol. 12, pp. 159-170, 2002

[31] S. Anjum and Q. A. Malik, "Determinants of corporate liquidity - An analysis of cash holdings," Journal of Business and Management, vol. 7, no. 2, pp. 94-100, 2013.

[32] T. Bates, K. Kahle, and R. Stulz, "Why do U.S. Firms hold so much more Cash than they used to?" The Journal of Finance, vol. LXIV, no. 5 .

[33] R. Zeitun and G. Tian, "Capital structure and corporate performance: Evidence from Jordan," Australasian Accounting, Business and Finance Journal, vol. 1, no. 4, pp. 40-61, 2007.

[34] P. Pratheepkanth, "Capital structure and financial performance: Evidence from selected business companies in Colombo stock exchange Sri Lanka," International Referred Research Journal, vol. 2 , no. 2,2011

[35] S. Owolabi and S. S. Ajao, "Liquidity management and corporate profitability: Case study of selected manufacturing companies listed on the Nigerian stock exchange," Business Management Dynamics, vol. 2 , no. 2, pp. 10-25, 2012.

[36] A. Bruinshoofd and C. Kool, "The determinants of corporate liquidity in the Netherlands," Maastricht University Working Paper; EFA 2002 Berlin Meetings Discussion Paper, 2002.

[37] N. Eriotis, "How firm characteristics affect capital structure: An empirical study," Managerial Finance, vol. 33, no. 5, pp. 321-331, 2007.

[38] R. E. Schumacker and R. G. Lomax, A Beginner's Guide to Structural Equation Modeling, New York: Taylor and Francis Group, 2010.

[39] K. A. Bollen, Structural Equation with Latent Variables, N.Y., USA: Wiley, 1989, p. 528

[40] J. J. Hair, R. Anderson, R. Tatham, and W. Black, Multivariate Data Analysis with Reading, 4th ed., Eagelwood Cliffs: Prentice Hall, 1995, p. 745

[41] J. Hox and T. Bechgrer, "An introduction to structural equation modeling," Family Science Review, pp. 354-373, 1998.

[42] A. Ghosh, "Does accounting based performance really improve following corporate acquisitions?" Working paper, Zickling School of Business, Baruch College (CU NY), New York, 1998.

[43] A. Gurbuz, A. Aybars, and O. Kutlu, "Corporate governance and financial performance with a perspective on institutional ownership: Empirical evidence from Turkey," Journal of Applied Management Accounting Research, vol. 8, no. 2, pp. 21-38, 2010

[44] B. Holmstrom and J. Tirole, "Private and public supply of liquidity," Journalof Political Economy, vol. 1, pp. 1-40, 1998.

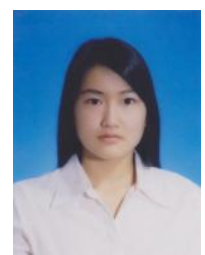

Janthorn Sinthupundaja was born in Bangkok Thailand, on June 17, 1991. She received her bachelor of engineering in Industrial Engineering (2nd Honor) from Sirindhorn International Institute of Technology (SIIT), Thammasat University in 2011 and is currently studying the master degree in logistics and supply chain systems engineering (LSCSE) at Sirindhorn International Institute of Technology (SIIT), Thammasat University, Pathum Thani, Thailand.

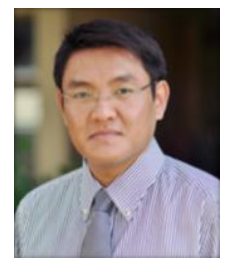

Navee Chiadamrong was born in Bangkok Thailand, on November 4, 1968. He received his MsC degree in engineering business management from Warwick University and $\mathrm{PhD}$ in manufacturing engineering and operations management from University of Nottingham, England. He is an associate professor at the School of Manufacturing Systems and Mechanical Engineering, Sirindhorn International Institute of Technology (SIIT), Thammasat Unversity. His research interests are in the area of production planning and control methods, performance evaluation and supply chain management. 